\title{
Microbial Ecology of Deep-Water Mid-Atlantic Canyons
}

Off the eastern coast of the United

States, several deep canyons cut through the continental shelf (fig. 1).

These canyons act like funnels for sediments to move from the shelf out to the deep seafloor. Exposed rock outcrops and ledges along the walls of these canyons provide important habitat for deep-sea corals and sponges.

A few scientific expeditions visited these canyons in the 1980s, mainly to map their shapes and to capture photographs of the bottom using manned submersibles and towed cameras (fig. 2). Our knowledge of the biodiversity in these complex ecosystems is limited; we know little about the macrofauna (fishes, crabs, sponges, and deep-sea corals) and even less about the microbiota (bacteria and fungi).

Why do the microbes matter?

Microbes are ecosystem architects! All underwater surfaces are rapidly covered in biofilms of living things, starting with microbes. The mixed community of bacteria in a particular biofilm can determine what other organisms will later choose to grow there. In this way, the microbes affect the eventual community structure of the visible fauna. Experiments will be conducted with settling plates at depths ranging from 150 to 1,000 meters (fig. $3 \mathrm{~A}$ ) to determine what types of microbial biofilms form on different surfaces. Stacks of settling plates will be mounted on benthic landers (weighted metal frames holding scientific instruments that are

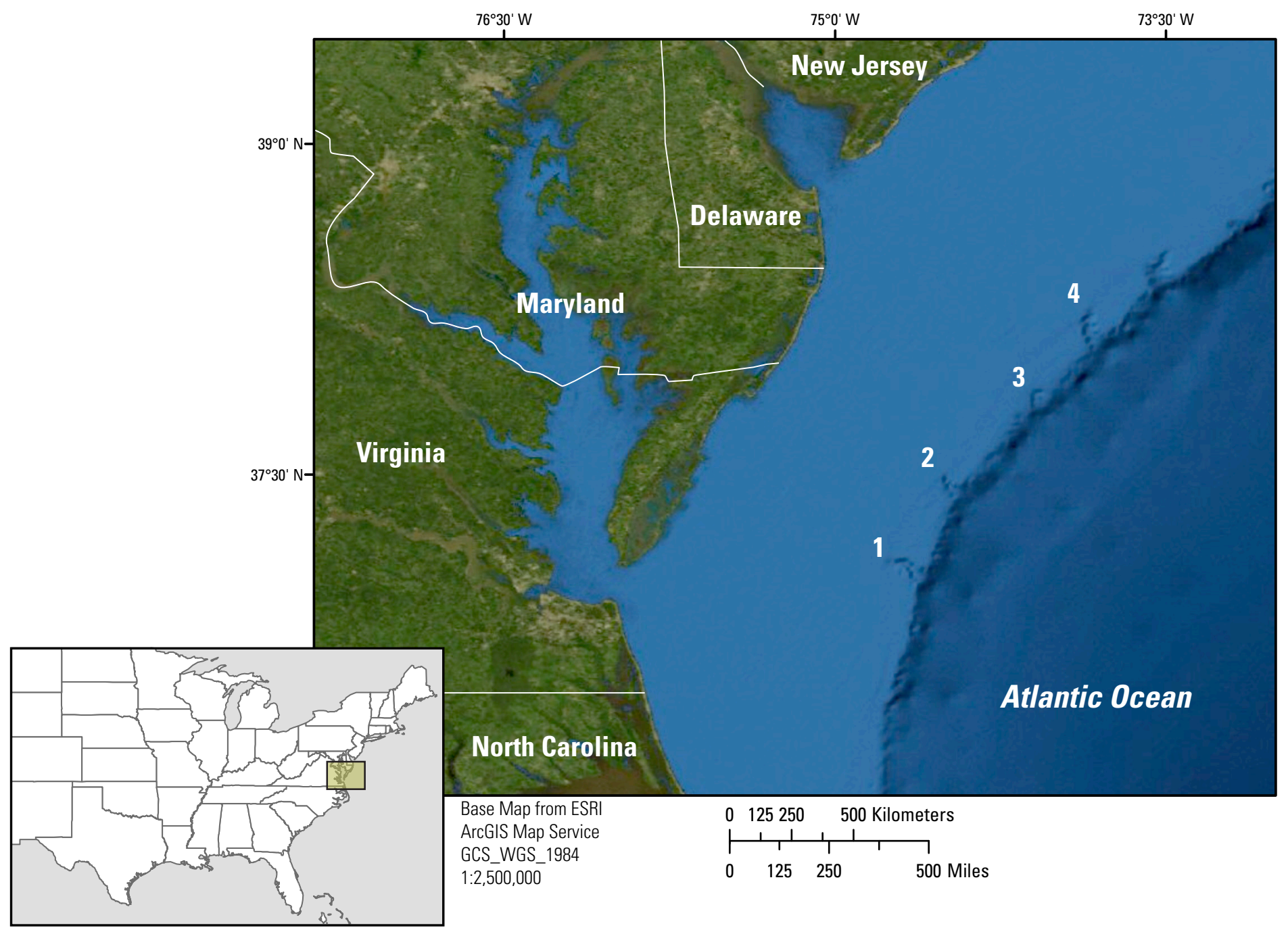

Figure 1. The eastern coast of the United States, showing deep undersea canyons cutting through the continental shelf. This project will focus on a number of canyons in the Mid-Atlantic Bight shown in the map above. 1: Norfolk Canyon, 2: Washington Canyon, 3: Accomac Canyon, and 4: Baltimore Canyon. 


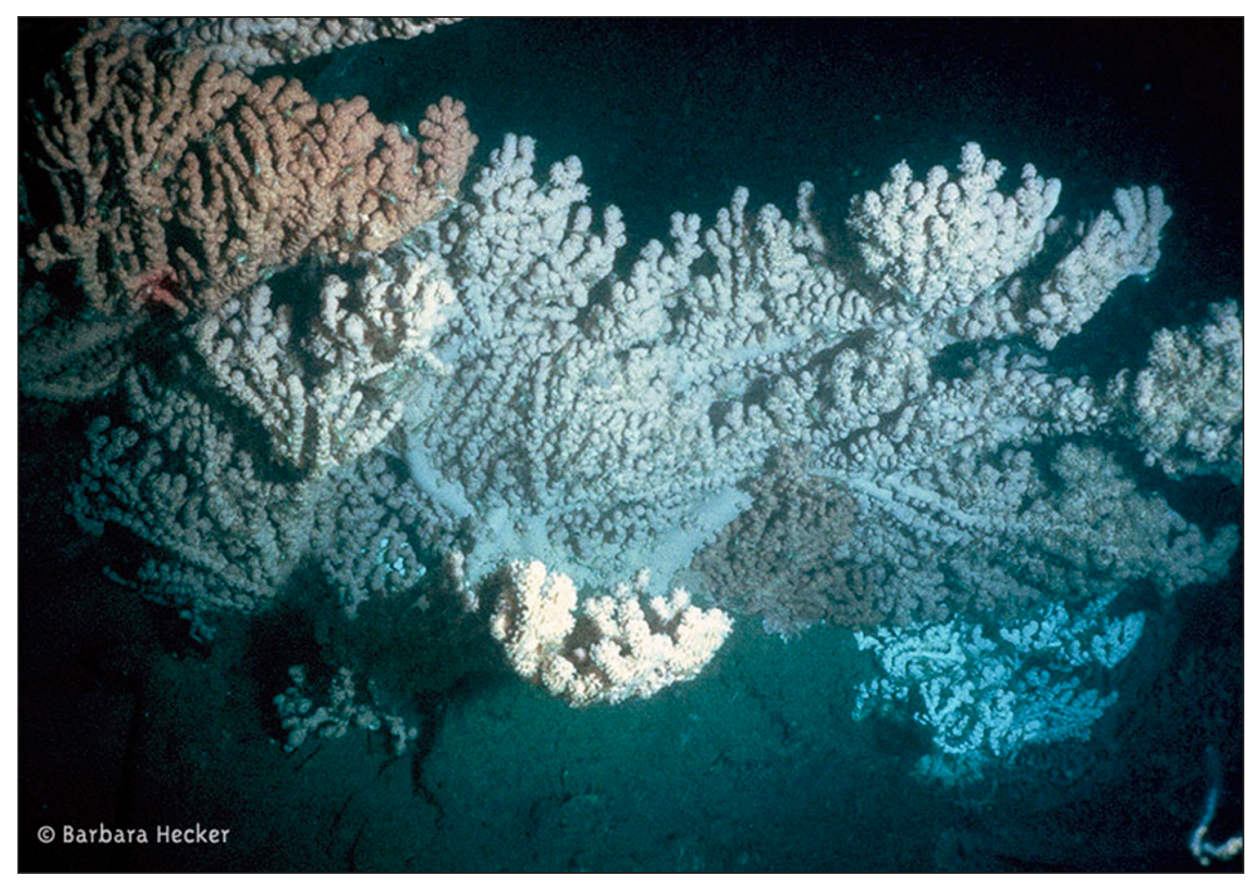

Figure 2. A cluster of deep-sea corals in Baltimore Canyon. Photo courtesy of Barbara Hecker, Hecker Environmental Consulting.

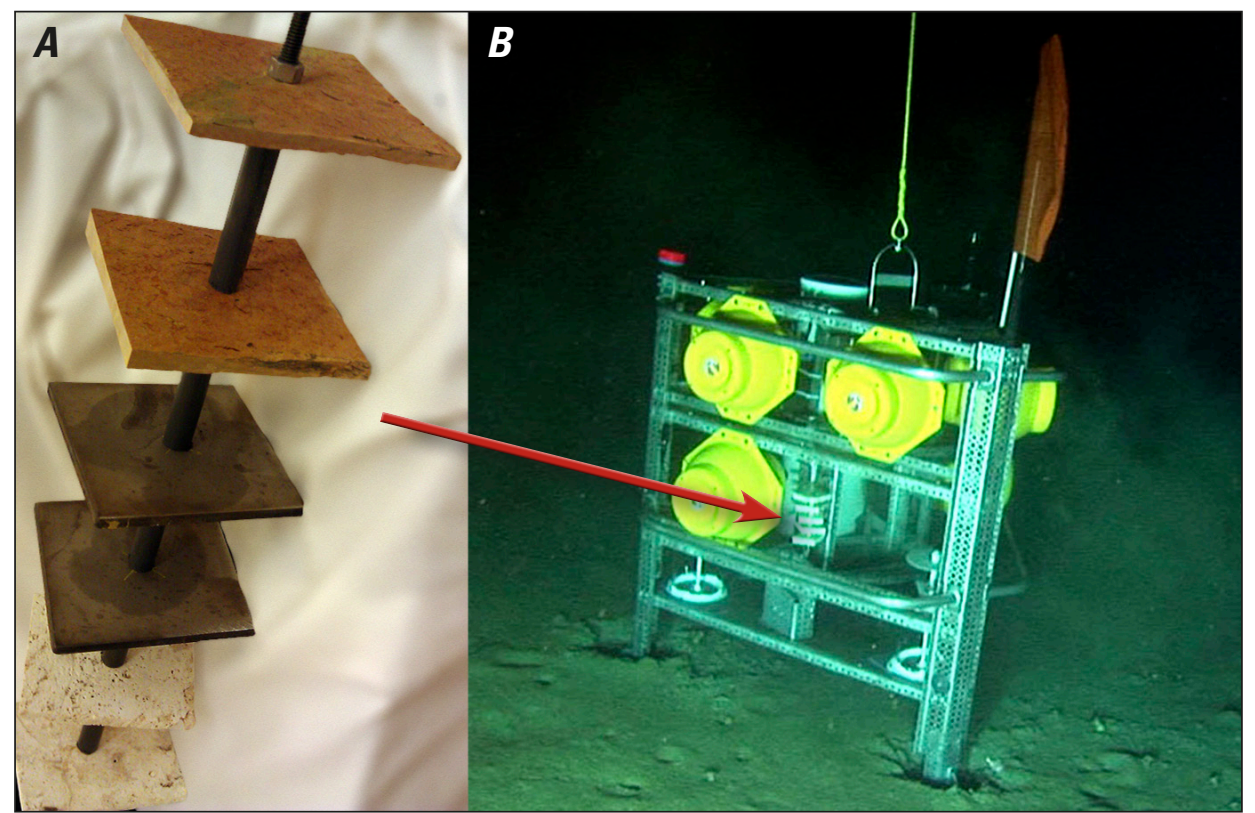

Figure 3. Experiments will be conducted using settling plates to determine what types of microbial biofilms form on different surfaces. $A$, Close-up of a stack of settling plates, featuring 4 inch $x 4$ inch $x 1 / 4$ inch limestone, steel, and sandstone settling plates; $B$, Stack of settling plates (arrow) deployed in deep water on a benthic lander. Photo $B$ courtesy of Steve Ross, University of North Carolina Wilmington (UNCW) and Sandra Brooke, Marine Conservation Institute (MCI).

\section{Contact Information:}

Christina A. Kellogg, Ph.D. Environmental Microbiologist

U.S. Geological Survey

St. Petersburg Science Center

600 4th Street South

St. Petersburg, FL 33701

PH: (727) 803-8747 x3128

FAX: (727) 803-2031

Email: ckellogg@usgs.gov

\section{http://fl.biology.usgs.gov/DISCOVRE/}

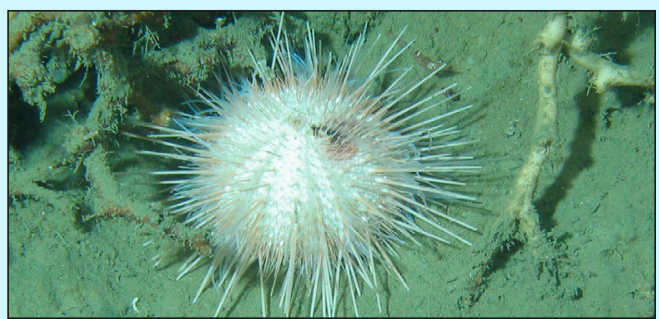

placed on the seafloor; fig. $3 B$ ) and left in the canyons for a year to accumulate biofilms that can then be analyzed to determine their microbial composition.

Microbes are also an important part of the biology of deep-sea corals. Just as we humans have beneficial bacteria living on our skin and in our intestines, corals also have co-habitating nonpathogenic (not disease-causing) microbes. These microorganisms are believed to help the corals by cycling nutrients and producing antimicrobial compounds that prevent unwanted microbes from infecting the corals. Fewer than 10 deep-sea coral species (out of hundreds) have had their microbial associates characterized. No corals from the mid-Atlantic canyons have yet been sampled to describe their microbial communities.

The soft sediments in the valleys of these canyons have their own community of small animals such as brittle stars and worms. Microbes serve as food for some of these animals. To enhance our understanding of the benthic ecology and food webs in deep-sea canyons, microbes in sediments will be counted and classified.

The research described in this fact sheet will be conducted from 2012 to 2014 as part of the U.S. Geological Survey's DISCOVRE (DIversity, Systematics, and COnnectivity of Vulnerable Reef Ecosystems) Program. This integrated, multidisciplinary effort will be investigating a variety of topics related to unique and fragile deep-sea ecosystems from the microscopic level to the ecosystem level, including components of microbiology, population genetics, paleoecology, food webs, taxonomy, community ecology, physical oceanography, and mapping.

Banner photograph courtesy of Ian MacDonald, Florida State University. 